\title{
Sebaran kasus dan faktor risiko kejadian DBD berbasis SIG Kabupaten Kubu Raya tahun 2016-2018
}

\author{
Syarif Syauqiannur ${ }^{1}$, Agus Fitriangga ${ }^{2}$, Muhammad Pramulya ${ }^{3}$ \\ 1. Program Studi Kedokteran, Fakultas Kedokteran, Universitas Tanjungpura; 2. Departemen \\ Kesehatan Masyarakat, Program Studi Kedokteran, Fakultas Kedokteran, Universitas Tanjungpura; 3. \\ Departemen Ilmu Perencanaan Wilayah, Program Studi D3 Budidaya Tanaman Perkebunan, Fakultas \\ Pertanian, Universitas Tanjungpura
}

Korespondensi: Syarif Syauqiannur; email: syarifsyauqiannur26@gmail.com

\begin{abstract}
Abstrak
Tujuan: Mengetahui gambaran hasil analisis spasial berdasarkan kasus kejadian, faktor risiko lingkungan pada kasus Demam Berdarah Dengue di wilayah kerja Puskesmas Sungai Durian Kabupaten Kubu Raya tahun 2016 - Juli 2018. Metode: Penelitian ini bersifat studi deskriptif kuantitatif dengan pendekatan cross-sectional berbasis Sistem Informasi Geografis (SIG). Hasil: Hasil penelitian Didapatkan bahwa gambaran Kasus DBD di Puskesmas Sungai Durian di tahun 2016 - Juli 2018 yaitu 13, 35, dan 37 kasus. Terjadi penurunan rata-rata suhu udara, curah hujan, diikuti dengan peningkatan jumlah kasus DBD. Semakin tinggi kepadatan penduduk maka kejadian DBD meningkat. Tidak menggunakan kawat kasa pada ventilasi rumah meningkatkan risiko kejadian DBD. Simpulan: Gambaran Kasus DBD di Puskesmas Sungai Durian di tahun 2016 - Juli 2018 terjadi peningkatan. Suhu udara mengalami penurunan dari $27,2^{\circ} \mathrm{C}$ ke $27,0^{\circ} \mathrm{C}$, dan curah hujan dari 409,0 ke $275,9 \mathrm{~mm} /$ hari namun terjadi peningkatan kasus DBD yaitu dari 13 menjadi 35 orang. Kepadatan penduduk yang paling tinggi terletak di desa Limbung yaitu $116,7 / \mathrm{km}^{2}$ dengan kejadian DBD sebanyak 17 kasus. Penggunaan kawat kasa pada ventilasi rumah masih sangat kecil hanya 19 rumah $(22,4 \%)$ dari total 85 rumah pasien kasus DBD.
\end{abstract}

Kata kunci: DBD; suhu udara; curah hujan; kepadatan penduduk; ventilasi rumah

\section{Abstract}

Objectives: To know the description results spatial analysis based on the case of events, environmental risk factors in cases of Dengue in Puskesmas Sungai Durian Kubu Raya Regency 2016 - July 2018. Methods: This study is a quantitative descriptive study cross-sectional using Geographic Information System (GIS) approach. Results: The results of the study showed that description of DHF cases in Puskesmas Sungai Durian in 2016-July 2018 was 13, 35, and 37 cases, there were decreased average air temperature, rainfall followed by an increased the number of dengue cases, the increase population density increases incidence of $D H F$, not using wire netting at home ventilation increases the risk of dengue incidence. Conclusions: Description of DHF cases in Puskesmas Sungai Durian in 2016-July 2018 was increased. The air temperature decreased from $27.2^{\circ} \mathrm{C}$ to $27.0^{\circ} \mathrm{C}$, and rainfall decreased from 409.0 to $275.9 \mathrm{~mm} /$ day but there was an increase in cases of DHF from 13 to 35 people, the highest population density was located in Limbung village, which was $116.7 / \mathrm{km}^{2}$ with 17 cases of DHF, the use of wire mesh on house ventilation was still very small, only 19 houses (22.4\%) out of a total 85 houses in DHF cases.

Keywords: DHF; air temperature; rainfall; population density; home ventilation 


\section{PENDAHULUAN}

Demam Berdarah Dengue (DBD) merupakan penyakit infeksi yang disebabkan oleh virus Dengue dan ditularkan melalui nyamuk terutama Aedes aegypti dan Aedes albopictus yang ditemukan di daerah tropis dan subtropis di antaranya kepulauan di Indonesia hingga bagian utara Australia. ${ }^{1}$ Pada banyak daerah tropis dan subtropis, penyakit DBD adalah endemis yang muncul sepanjang tahun, terutama saat musim hujan ketika kondisi optimal untuk nyamuk berkembang biak. Biasanya sejumlah besar orang akan terinfeksi dalam waktu yang singkat (wabah). ${ }^{2}$

Sebelum tahun 1970 hanya 9 negara yang mengalami wabah DBD, namun sekarang DBD menjadi penyakit endemis pada lebih dari 100 negara. Pada tahun 2013 dilaporkan terdapat sebanyak 2,35 juta kasus di Amerika, dimana 37.687 kasus merupakan DBD berat. Selain di Amerika, transmisi penyebaran DBD sudah mencapai ke benua Eropa khususnya pada tahun 2010 di Perancis dan Kroasia. Pada tahun 2012, terjadi lebih dari 2.000 kasus DBD pada lebih dari 10 negara di Eropa. Setidaknya 500.000 penderita DBD memerlukan rawat inap setiap tahunnya, dimana proporsi penderita sebagian besar adalah anak-anak dan 2,5\% diantaranya dilaporkan meninggal dunia. ${ }^{3}$

Tahun 2014 terdapat 5 provinsi dengan Incindence Rate (IR) per 100.000 penduduk di Indonesia yang tertinggi yaitu Bali dengan IR 204,20\%, Kalimantan Timur dengan IR 131,10\%, kemudian Kalimantan Tenggara dengan IR $128,50 \%$, dan di posisi ke empat yaitu Kalimantan Barat dengan IR sebesar $111,10 \%$, kelima yaitu Kepulauan Riau 92,60\%. ${ }^{1}$ Berdasarkan data Dinas Kesehatan Kalimantan Barat, dalam kurun waktu 5 tahun dari 2011-2015 kasus kejadian DBD terjadi cukup fluktuatif, berturut-turut mulai dari 2011 terjadi 784 kasus (Angka Kematian/Case Fatality Rate (CFR): 1,3\%), tahun 2012 ada 1614 kasus (CFR: 1,4\%), tahun 2013 ada 838 kasus (CFR: 1,7\%), tahun 2014 ada 5.049 kasus (CFR: 1,3\%), dan tahun 2015 ada 951 kasus (CFR: $1,6 \%) .{ }^{4}$

Tahun 2015 Kabupaten Kubu Raya sendiri menempati posisi ketiga terbanyak kasus DBD di Kalimantan Barat di bawah Ketapang dan Sintang, dan di atas dari kota Pontianak, dengan kasus DBD di kabupaten Kubu Raya yaitu 103 Kasus (dengan Angka Kematian sebesar 10,83\%). ${ }^{4}$ Berdasarkan data Dinas Kesehatan Kabupaten Kubu Raya untuk kasus DBD di Kubu Raya juga menunjukkan angka kejadian yang fluktuatif yaitu misalnya dari kurun waktu 5 tahun terakhir yaitu 2012-2016, secara berturut-turut yaitu pada tahun 2012 sebanyak 195 kasus DBD, tahun 2013 sebanyak 127 kasus DBD, tahun 2014 sebanyak 603 kasus DBD, dan 2016 sebanyak 30 kasus DBD. Pada tahun 2017 dari bulan Januari-Juni yaitu sebanyak 39 kasus DBD. Pada tahun 2017 Kecamatan Sungai Raya juga tercatat merupakan kecamatan dengan kejadian kasus DBD terbanyak yaitu sebanyak 23 Kasus dari 39 kasus yang terjadi di Kabupaten Kubu Raya, 
dan IR DBD di kecamatan Sungai Raya terbesar terjadi di wilayah kerja puskesmas Sungai Durian yaitu sebesar 68,9\% (14 Kasus). ${ }^{5}$

Berdasarkan data Puskesmas Sungai Durian, terdapat 8 Desa yang termasuk wilayah kerja Puskesmas Sungai Durian yaitu Teluk Kapuas, Arang Limbung, Limbung, Kuala Dua, Sungai Ambangah, Madu Sari, Tebang Kacang, dan Mekar Sari. Pada tahun 2016 tercatat terjadi kasus DBD sebanyak 13 kasus di wilayah kerja Puskesmas Sungai Durian. Pada tahun 2017 tercatat terjadi kasus DBD sebanyak 35 kasus di wilayah kerja Puskesmas Sungai Durian (terbanyak di desa Kuala Dua yaitu 12 kasus). Pada tahun 2018 (bulan JanuariJuli) sudah tercatat terjadi kasus DBD sebanyak 37 kasus di wilayah kerja Puskesmas Sungai Durian. Total kejadian DBD di wilayah kerja Puskesmas Sungai Durian dari tahun 2016 - Juli 2018 adalah sebanyak 85 kasus. $^{6}$

Sistem Informasi Geografi (SIG) merupakan salah satu metode penting untuk surveilans dan monitoring kesehatan masyarakat. Hal ini karena fungsi SIG dalam bidang kesehatan yang dapat menghasilkan gambaran spasial dari peristiwa kesehatan, menganalisis hubungan antar lokasi, lingkungan dan kejadian penyakit. Selain itu SIG dapat men-stratifikasi faktor risiko suatu penyakit berdasarkan kondisi lingkungan. ${ }^{7,8}$

Faktor lingkungan juga memiliki peranan dalam menyebabkan kejadian DBD, hal ini dikarenakan kondisi lingkungan baik fisik, biologis, maupun sosial dapat mempengaruhi transmisi virus dan vektor Dengue. ${ }^{9}$ Berdasarkan hasil penelitian yang dilakukan oleh Sibe et al. (2010) di Kabupaten Wajo, kondisi lingkungan fisik merupakan faktor dominan risiko kejadian DBD. ${ }^{10}$

Berdasarkan hasil studi pendahuluan yang peneliti lakukan pada bulan September tahun 2017 di bagian P2M Dinas Kesehatan Kubu Raya didapatkan informasi bahwa belum tersedia data mengenai faktor risiko kejadian DBD di wilayah kerja Puskesmas Sungai Durian dengan berbasis SIG (Sistem Informasi Geografi). Perlu dilakukan pendekatan secara spasial untuk mengetahui faktor risiko lingkungan yang menjadi penyebab utama penularan DBD dan untuk meningkatkan kesadaran dan kewaspadaan penyakit DBD di wilayah kerja Puskesmas Sungai Durian tersebut karena beragamnya karakteristik lingkungan pada masing-masing desa/lokasi. Oleh karena itu, peneliti tertarik untuk meneliti topik tersebut.

\section{METODE}

Penelitian ini bersifat studi deskriptif kuantitatif dengan pendekatan crosssectional, dengan tujuan untuk membuat analisis spasial sebaran kasus DBD di wilayah kerja Puskesmas Sungai Durian Kecamatan Sungai Raya Kabupaten Kubu Raya Provinsi Kalimantan Barat tahun 2016-2018.

Populasi dalam penelitian ini adalah seluruh pasien Demam Berdarah Dengue di Kalimantan Barat. Populasi target di 
dalam penelitian ini adalah seluruh pasien Demam Berdarah Dengue di Kabupaten Kubu Raya, sementara populasi terjangkau dalam penelitian ini adalah seluruh pasien Demam Berdarah Dengue di wilayah kerja Puskesmas Sungai Durian. Sampel yang akan diteliti pada penelitian ini adalah seluruh pasien Demam Berdarah Dengue yang berobat dan terdapat data di Puskesmas Sungai Durian dari tahun 2016 Juli 2018 yaitu sebanyak 85 kasus yang akan menggunakan teknik total sampling. Instrumen yang digunakan dalam penelitian ini adalah peta lokasi, Global Positioning System (GPS), alat fotografi, perangkat lunak GIS dan SPSS.

\section{HASIL DAN PEMBAHASAN}

Puskesmas Sungai Durian merupakan satu dari tiga puskesmas di wilayah Kecamatan Sungai Raya Kabupaten Kubu Raya. Wilayah kerja Puskesmas mencakup delapan desa binaan, yaitu Desa Limbung, Arang Limbung, Teluk Kapuas, Kuala Dua, Tebang Kacang, Sungai Ambangah ditambah dua desa pemekaran pada tahun 2006 yaitu Desa Mekar Sari, dan Desa Madu Sari. ${ }^{11}$ Gambaran peta wilayah lokasi penelitian dapat dilihat di gambar 1 di bawah ini.

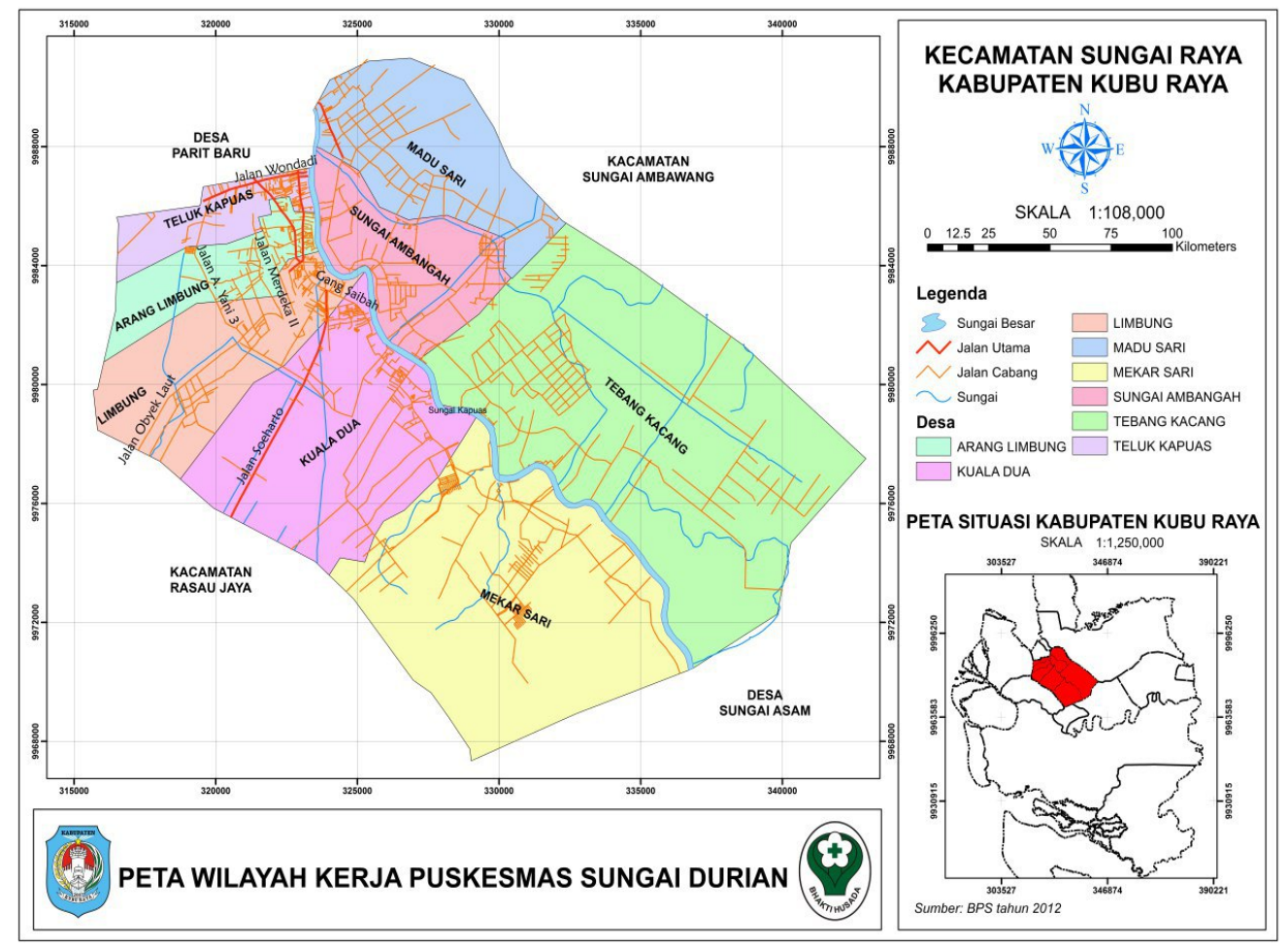

Gambar 1. Peta wilayah lokasi penelitian

Jumlah penduduk di wilayah kerja Puskesmas Sungai Durian dari hasil pendataan keluarga pada tahun 2016 sebesar 100.892 jiwa dengan 23.300 KK jumlah rumah unit, kepadatan hunian sekitar $31 \mathrm{~km}^{2} .{ }^{11}$ Luas Wilayah Administrasi Pemerintahan, Jumlah Penduduk dan Kepadatan Penduduk wilayah Kerja 
Puskesmas Sungai Durian tahun 2016 terdapat pada tabel 1.

Berdasarkan data tabel di atas didapatkan hasil bahwa ada 4 desa/wilayah yang memiliki kepadatan penduduk yang lebih tinggi dan angka kasus DBD yang terbanyak pula jika dibandingkan dengan desa/wilayah lainnya yaitu desa Limbung dengan kepadatan penduduk sebesar $116,7 / \mathrm{km}^{2}$ (17 kasus DBD), desa Arang Limbung dengan kepadatan penduduk sebesar 93,6/km² (21 kasus DBD), desa Teluk Kapuas dengan kepadatan penduduk sebesar $69,0 / \mathrm{km}^{2}$ (14 kasus DBD), dan yang terakhir yaitu desa Kuala Dua dengan kepadatan penduduk $57,1 / \mathrm{km}^{2}$ (28 kasus DBD). Sedangkan wilayah atau desa yang memiliki kepadatan penduduk di bawah 20/km² yaitu Sungai Ambangah (1 kasus DBD), Madu Sari (0 kasus DBD), Tebang Kacang (2 kasus DBD) dan Mekar Sari (2 kasus DBD) hanya ditemukan sedikit kasus DBD, hal ini dapat dikatakan bahwa kepadatan penduduk berpengaruh dengan tingginya angka kejadian DBD di wilayah kerja Puskesmas Sungai Durian. ${ }^{12}$

Tabel 1. Luas Wilayah Administrasi Pemerintahan, Jumlah Penduduk dan Kepadatan Penduduk wilayah Kerja Puskesmas Sungai Durian tahun 2016

\begin{tabular}{|c|c|c|c|c|}
\hline No. & $\begin{array}{l}\text { Desa wilayah kerja } \\
\text { Puskesmas }\end{array}$ & Luas wilayah $\left(\mathrm{km}^{2}\right)$ & Jumlah penduduk & $\begin{array}{l}\text { Kepadatan } \\
\text { penduduk per } \mathrm{km}^{2}\end{array}$ \\
\hline 1. & Teluk Kapuas & 18.860 & 13.018 & 69,0 \\
\hline 2. & Arang Limbung & 21.500 & 20.133 & 93,6 \\
\hline 3. & Limbung & 13.390 & 26.479 & 116,7 \\
\hline 4. & Kuala Dua & 46.870 & 24.723 & 57,1 \\
\hline 5. & Sungai Ambangah & 31.630 & 5.381 & 17,0 \\
\hline 6. & Madu Sari & 24.110 & 3.380 & 14,0 \\
\hline 7. & Tebang Kacang & 82.570 & 5.124 & 6,2 \\
\hline 8. & Mekar Sari & 82.470 & 12.117 & 14,7 \\
\hline \multicolumn{2}{|c|}{ Jumlah } & 321.400 & 98.591 & 31 \\
\hline
\end{tabular}

Kepadatan penduduk merupakan salah satu faktor yang terkait dalam penularan DBD pada manusia, hal ini terjadi karena jarak terbang nyamuk yang menjadi vektor penular diperkirakan hanya sekitar 40-100 meter.3 Oleh karena itu, wilayah dengan kepadatan penduduk yang tinggi menandakan risiko penularan melalui nyamuk harus diwaspadai, karena kemampuan daya terbang nyamuk yang cukup dekat.

Suhu udara di Kecamatan Sungai Raya yang termasuk dalam Kabupaten Kubu Raya menurut Data Bulanan Stasiun Meteorologi Supadio 3 tahun terakhir dari bulan Januari sampai Desember menunjukkan angka yang cukup stabil. Pada tahun 2015, suhu udara rata-rata selama setahun adalah $26,9^{\circ} \mathrm{C}$. Pada tahun 2016, suhu udara rata-rata selama setahun adalah $27,2^{\circ} \mathrm{C}$. Pada tahun 2017, suhu udara rata-rata selama setahun adalah $27^{\circ} \mathrm{C}$. Untuk lebih lengkapnya dapat dilihat pada gambar 2 .

Suhu udara di Kecamatan Sungai Raya pada tahun 2016 mempunyai rata-rata 
suhu sebesar $27,2^{\circ} \mathrm{C}$ dimana pada tahun tersebut didapatkan jumlah pasien DBD sebanyak 13 Orang di wilayah kerja Puskesmas Sungai Durian dan pada tahun berikutnya yaitu tahun 2017 dengan rata- rata suhu udara di Kecamatan Sungai Raya tersebut mengalami penurunan yaitu menjadi $27,0^{\circ} \mathrm{C}$ namun dengan peningkatan jumlah kasus DBD menjadi 35 Orang dalam tahun tersebut.
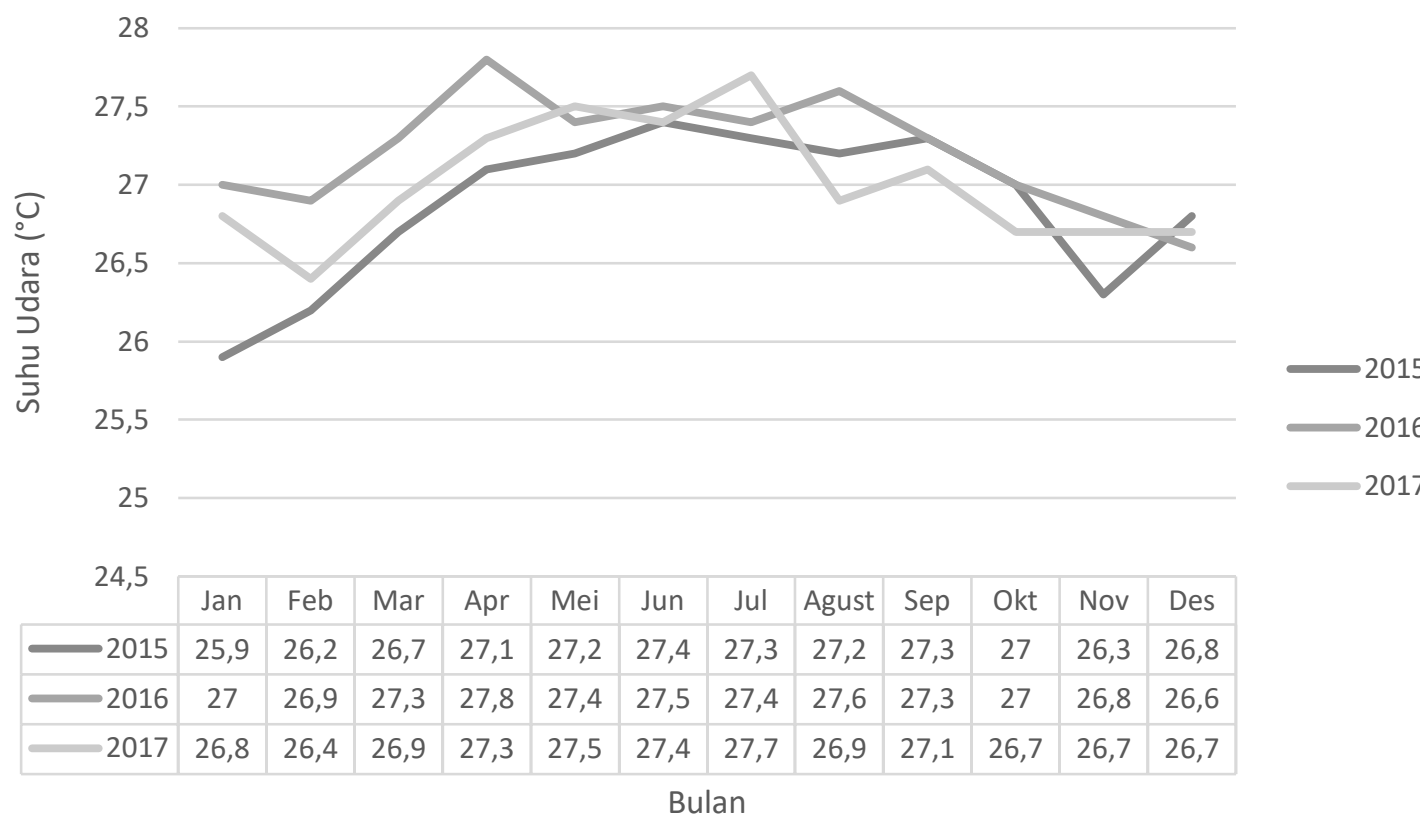

Gambar 2. Grafik Data Bulanan Suhu Udara Kabupaten Kubu Raya

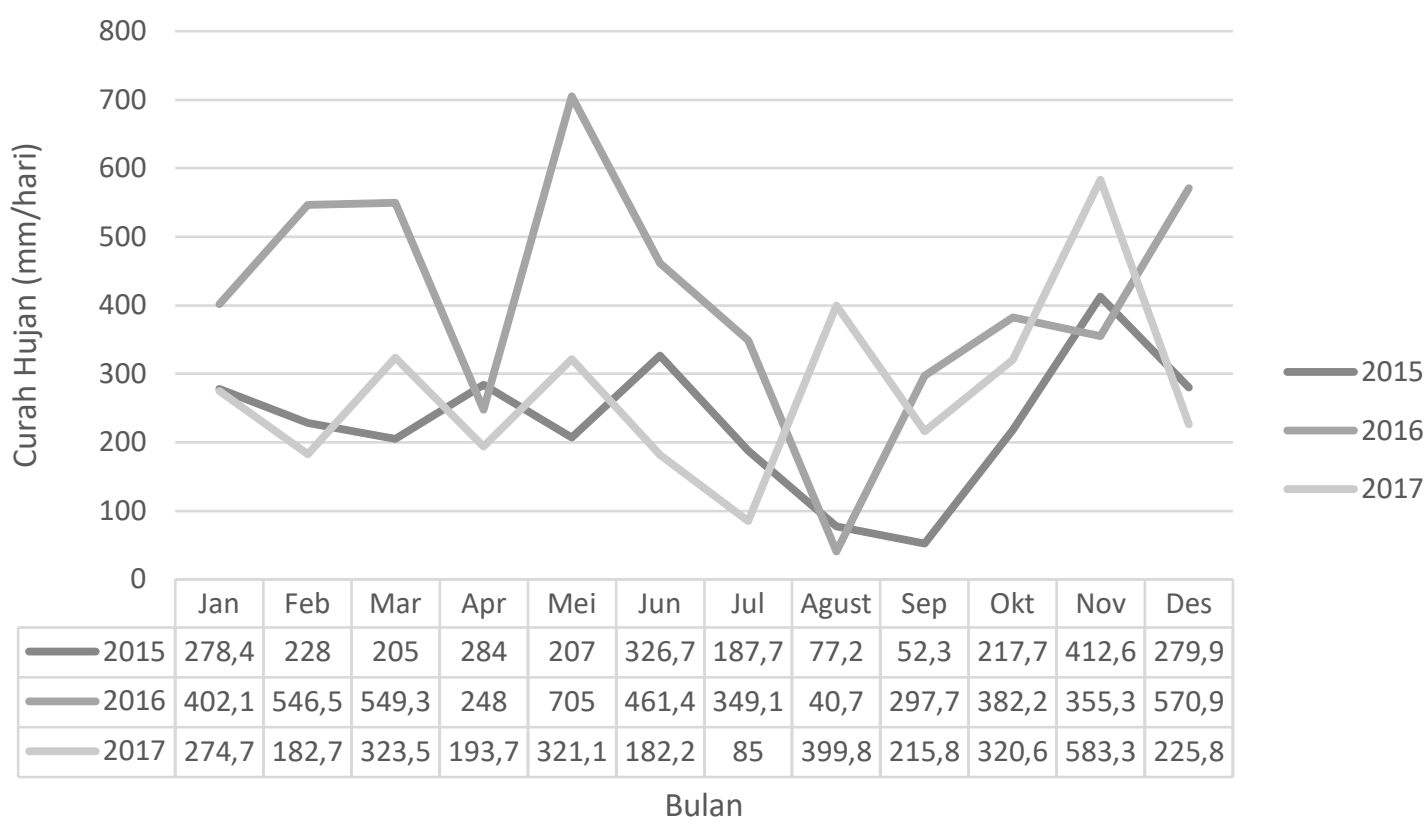

Gambar 3. Data Bulanan Curah Hujan Kabupaten Kubu Raya 
Berdasarkan data di atas, diketahui dalam 2 tahun terakhir terjadi penurunan suhu udara rata-rata dan diikuti oleh peningkatan kasus DBD. Hal ini menunjukkan bahwa semakin rendah suhu udara di suatu lingkungan, akan meningkatkan angka kejadian atau kasus DBD. Diketahui bahwa suhu udara sangat erat kaitannya dengan kelembaban udara, dimana semakin rendah suhu udara, maka kelembaban udaranya akan semakin tinggi.

Suhu udara rata-rata $26^{\circ} \mathrm{C}-28,5^{\circ} \mathrm{C}$ merupakan suhu yang sangat baik atau optimal untuk perkembangan nyamuk Aedes sp. dalam perannya untuk peningkatan kasus DBD, hal ini sesuai dengan penelitian Arifatun Nissa, dimana apabila suhu udara kurang dari $26^{\circ} \mathrm{C}$ dan atau lebih dari $28,5^{\circ} \mathrm{C}$ atau di atas $35^{\circ} \mathrm{C}$ (Suhu Ekstrem) kasus akan berkurang karena akan mengalami perubahan dalam arti lebih lambatnya proses fisiologi. Serta hasil penelitiannya yaitu hasil uji keeratan korelasi antara suhu dengan kejadian DBD menunjukkan korelasi arah negatif yang artinya jumlah kejadian DBD meningkat sebanding dengan penurunan suhu udara, semakin lembap atau rendah suhu udara suatu lingkungan maka akan meningkatnya angka kejadian DBD (namun tidak melebihi suhu ekstrem). ${ }^{13}$

Berdasarkan gambar 3 di atas hasil dari curah hujan di Kecamatan Sungai Raya yang termasuk dalam Kabupaten Kubu Raya menurut Data Bulanan Stasiun Meteorologi Supadio 3 tahun terakhir dari bulan Januari sampai Desember. Pada tahun 2015, curah hujan rata-rata selama setahun adalah 229,7 mm/hari. Pada tahun 2016, curah hujan rata-rata selama setahun adalah 409,0 mm/hari. Pada tahun 2017, curah hujan rata-rata selama setahun adalah $275,9 \mathrm{~mm} /$ hari.

Curah Hujan di Kecamatan Sungai Raya pada tahun 2016 mempunyai rata-rata sebesar 409,0 mm/hari dimana pada tahun tersebut didapatkan jumlah pasien DBD sebanyak 13 Orang di wilayah kerja Puskesmas Sungai Durian dan pada tahun berikutnya yaitu tahun 2017 dengan ratarata curah hujan di Kecamatan Sungai Raya tersebut mengalami penurunan yaitu menjadi 275,9 mm/hari namun dengan peningkatan jumlah kasus DBD menjadi 35 Orang dalam tahun tersebut. Berdasarkan data tersebut maka penelitian yang didapatkan tidak sejalan dikarenakan terjadinya peningkatan jumlah kasus DBD di saat curah hujan menurun dari tahun 2016 ke tahun 2017. Hal ini terjadi dikarenakan tidak adanya survei dan penyaksian secara langsung untuk variabel curah hujan dan ada faktor lain yang memengaruhi tingginya kasus DBD pada tahun terkait.

Hujan adalah peristiwa sampainya air dalam bentuk cair maupun padat yang dicurahkan dari atmosfer ke permukaan bumi. Curah hujan yaitu jumlah air hujan yang turun pada suatu daerah dalam waktu tertentu. Alat untuk mengukur banyaknya curah hujan disebut rain gauge. Curah hujan diukur dalam harian, bulanan, dan tahunan. ${ }^{14}$ 
Semakin tinggi rata-rata curah hujan seharusnya semakin meningkatkan angka kejadian DBD karena curah hujan yang tinggi akan berpengaruh terhadap suhu udara juga, dan di saat musim kemarau yang biasanya akan banyak sampahsampah buangan manusia dan saat musim hujan sampah-sampah tersebut akan sangat baik untuk perkembangan nyamuknyamuk Aedes sp. dan vektor penyakit lainnya. Hal ini juga sejalan dengan penelitian yang dilakukan oleh Mangole dkk. tahun 2016. Arah kecenderungan yang positif menandakan bahwa setiap kenaikan curah hujan akan diikuti kenaikan jumlah DBD. ${ }^{15}$

Tabel 2. Gambaran Keberadaan Kawat Kasa pada Ventilasi Rumah Pasien DBD di Wilayah Kerja Puskesmas Sungai Durian 2016- July 2018

\begin{tabular}{|c|c|c|c|c|c|c|c|c|}
\hline \multirow{3}{*}{ No. } & \multirow{3}{*}{$\begin{array}{c}\text { Desa/wilayah kerja } \\
\text { Puskesmas Sungai } \\
\text { Durian }\end{array}$} & \multicolumn{6}{|c|}{ Ventilasi berkasa pada tahun } & \multirow{3}{*}{$\begin{array}{l}\text { Total kasus DBD } \\
2016 \text { - Juli } 2018\end{array}$} \\
\hline & & \multicolumn{2}{|c|}{2016} & \multicolumn{2}{|c|}{2017} & \multicolumn{2}{|c|}{ Jan-Jul 2018} & \\
\hline & & Ya & Tidak & Ya & Tidak & Ya & Tidak & \\
\hline 1. & Teluk Kapuas & 1 & 0 & 3 & 8 & 0 & 2 & 14 kasus DBD \\
\hline 2. & Arang Limbung & 1 & 3 & 2 & 7 & 2 & 6 & 21 kasus DBD \\
\hline 3. & Limbung & 0 & 4 & 0 & 0 & 3 & 10 & 17 kasus DBD \\
\hline 4. & Kuala Dua & 1 & 3 & 3 & 10 & 3 & 8 & 28 kasus DBD \\
\hline 5. & Sungai Ambangah & 0 & 0 & 0 & 0 & 0 & 1 & 1 kasus DBD \\
\hline 6. & Madu Sari & 0 & 0 & 0 & 0 & 0 & 0 & 0 kasus DBD \\
\hline 7. & Tebang Kacang & 0 & 0 & 0 & 1 & 0 & 1 & 2 kasus DBD \\
\hline 8. & Mekar Sari & 0 & 0 & 0 & 1 & 0 & 1 & 2 kasus DBD \\
\hline Total & & 3 & 10 & 8 & 27 & 8 & 29 & 85 rumah \\
\hline
\end{tabular}

Berdasarkan data tabel 2 yang didapatkan oleh peneliti saat melakukan observasi langsung didapatkan bahwa sebagian besar rumah-rumah pasien yang mengalami DBD tidak menggunakan kawat kasa pada ventilasi rumahnya. Terdapat 8 desa/wilayah kerja yang observasi peneliti dan ditemukan pada 4 desa terbesar angka kejadian DBD nya dari tahun 2016 - Juli 2018 yaitu desa Teluk Kapuas dari 14 kasus DBD/rumah pasien hanya 4 rumah yang menggunakan kawat kasa pada ventilasi rumahnya sedangkan 10 rumah tidak. Desa Arang Limbung dari 21 kasus DBD/rumah pasien hanya 5 rumah yang menggunakan kawat kasa pada ventilasi rumahnya sedangkan 16 rumah tidak. Desa Limbung dari 17 kasus DBD/rumah pasien hanya 3 rumah yang menggunakan kawat kasa pada ventilasi rumahnya sedangkan 14 rumah tidak. Desa Kuala Dua dari 28 kasus $\mathrm{DBD} /$ rumah pasien hanya 7 rumah yang menggunakan kawat kasa pada ventilasi rumahnya sedangkan 21 rumah tidak. Hal ini menunjukkan bahwa rumah-rumah pasien yang terkena penyakit DBD masih lebih banyak yang tidak menggunakan kawat kasa pada ventilasi rumahnya dibandingkan dengan yang menggunakan kawat kasa di ventilasi rumahnya yang bertujuan sebagai langkah pencegahan untuk menghindari mudahnya keluar masuk nyamuk Aedes sp. ${ }^{16,17}$

Pemasangan kawat kasa ini merupakan salah satu pengendalian vektor nyamuk secara fisik/mekanik, yang idealnya jumlah 
lubangnya $14-16$ per inci $(2,5 \mathrm{~cm})$ dan terbuat dari aluminium atau plastik. ${ }^{18}$ Penelitian ini sejalan dengan penelitian yang dilakukan Maria, Ishak dan Selomo (2013) di Makassar juga menemukan bahwa terdapat hubungan yang signifikan antara keberadaan kawat kasa dengan kejadian DBD, dimana kondisi rumah yang tidak memiliki kawat kasa lebih berisiko 9,04 kali dibandingkan dengan yang memiliki kawat kasa. ${ }^{19}$

Tabel 3. Distribusi jumlah pasien DBD tahun 2016 - Juli 2018

\begin{tabular}{|c|c|c|c|c|c|c|}
\hline \multirow[t]{2}{*}{ Desa } & \multicolumn{2}{|c|}{2016} & \multicolumn{2}{|c|}{2017} & \multicolumn{2}{|c|}{2018} \\
\hline & $\mathrm{N}$ & $\%$ & $\mathrm{~N}$ & $\%$ & $\mathrm{~N}$ & $\%$ \\
\hline Arang Limbung (AL) & 4 & 30,8 & 9 & 25,7 & 8 & 21,6 \\
\hline Kuala Dua (KD) & 4 & 30,8 & 13 & 37,1 & 11 & 29,7 \\
\hline Teluk Kapuas (TK) & 1 & 7,6 & 11 & 31,4 & 2 & 5,4 \\
\hline Limbung (L) & 4 & 30,8 & 0 & 0,0 & 13 & 35,2 \\
\hline Mekar Sari (MS) & 0 & 0,0 & 1 & 2,9 & 1 & 2,7 \\
\hline Sungai Ambangah (SA) & 0 & 0,0 & 0 & 0,0 & 1 & 2,7 \\
\hline Tebang Kacang (TBK) & 0 & 0,0 & 1 & 2,9 & 1 & 2,7 \\
\hline Madu Sari (MSA) & 0 & 0,0 & 0 & 0,0 & 0 & 0,0 \\
\hline Total & 13 & 100,0 & 35 & 100,0 & 37 & 100,0 \\
\hline
\end{tabular}

Berdasarkan data yang terdapat pada tabel 3 dan gambar 4 yang didapatkan di Puskesmas Sungai Durian pada tahun 2016, 2017, dan Januari-Juli 2018, pasien DBD didapatkan tahun 2016 yaitu usia <15 tahun ada 5 orang $(38,5 \%)$ dan usia 15-55 tahun ada 7 orang (53,8\%); tahun 2017, usia $<15$ tahun ada 28 orang $(79,7 \%)$ dan usia $15-55$ tahun hanya 7 orang $(20,3 \%)$; Januari-Juli 2018, usia <15 tahun ada 32 orang $(86,5 \%)$ dan usia $15-55$ tahun hanya ada 5 orang $(13,5 \%)$. Hal ini menunjukkan bahwa pasien DBD di wilayah kerja Puskesmas Sungai Durian dari tahun 2016 Juli 2018 banyak diderita oleh kelompok usia $<15$ tahun.

Berdasarkan jenis kelamin pada tahun 2016-Juli 2018 didapatkan total selama 3 tahun terakhir dari 85 sampel yang diperoleh terdapat pasien yang menderita
DBD di Wilayah Kerja Puskesmas Sungai Durian adalah 46 orang laki-laki $(54,1 \%)$ dan 39 orang perempuan $(45,9 \%)$. Hal ini menunjukkan bahwa tidak terlalu jauh berbeda antara laki-laki dan perempuan terhadap tingginya kasus DBD yang terjadi. Sejalan dengan hasil penelitian Rizza Umaya didapatkan bahwa tidak ada hubungan antara jenis kelamin terhadap kejadian DBD diwilayah kerja Puskesmas Talang Ubi Pendopo Tahun 2012. Hal ini dapat dilihat dari nilai $p=0,996(p>0,05)$. Ini menunjukkan bahwa jenis kelamin responden tidak memiliki pengaruh terhadap kejadian DBD. Selain itu, berdasarkan hasil penelitian yang dilakukan oleh Yusnia, kasus DBD lebih banyak ditemukan pada laki-laki sebanyak 107 kasus (52,2\%) daripada perempuan 98 kasus $(47,8 \%))^{20,21}$ 


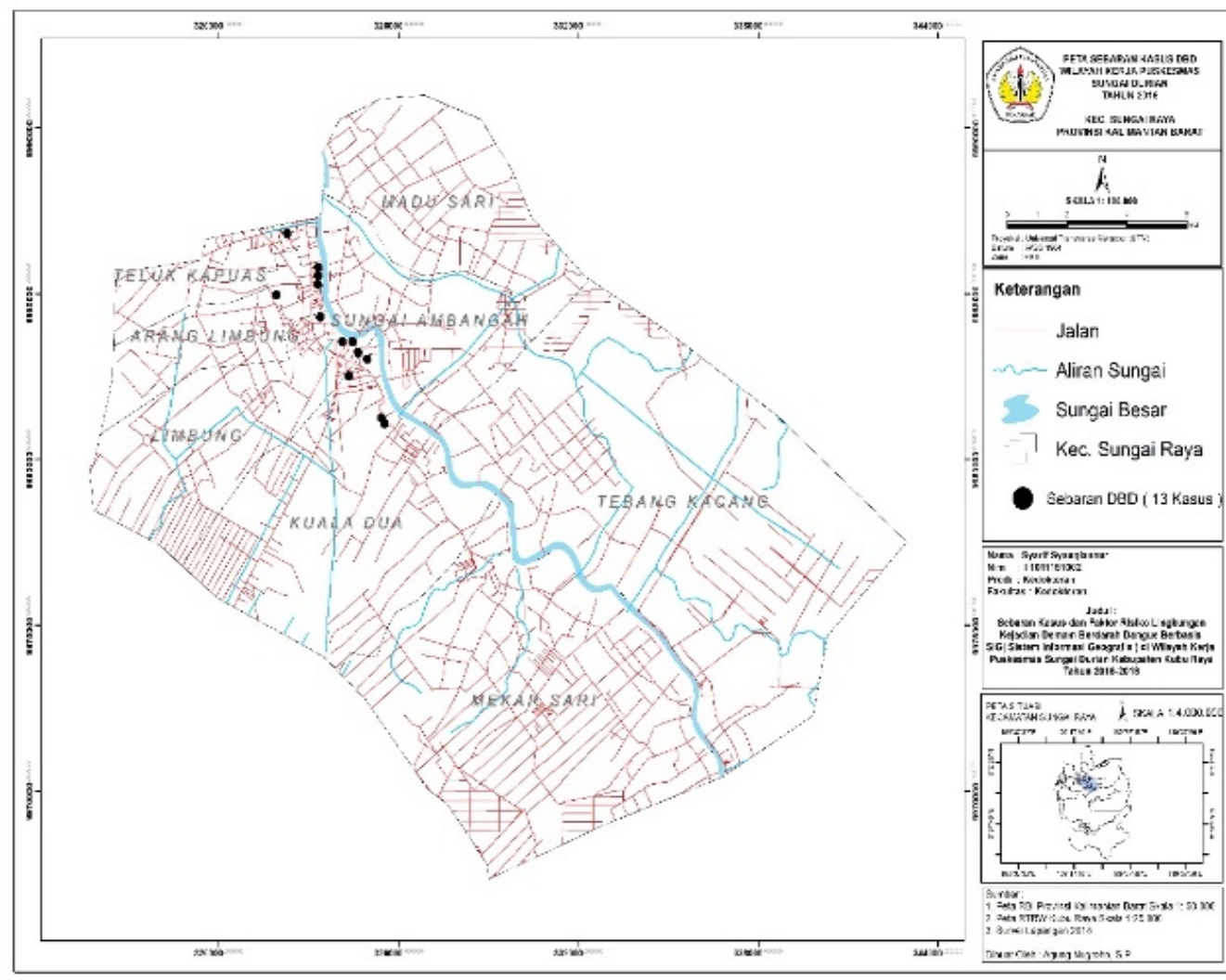

(a)

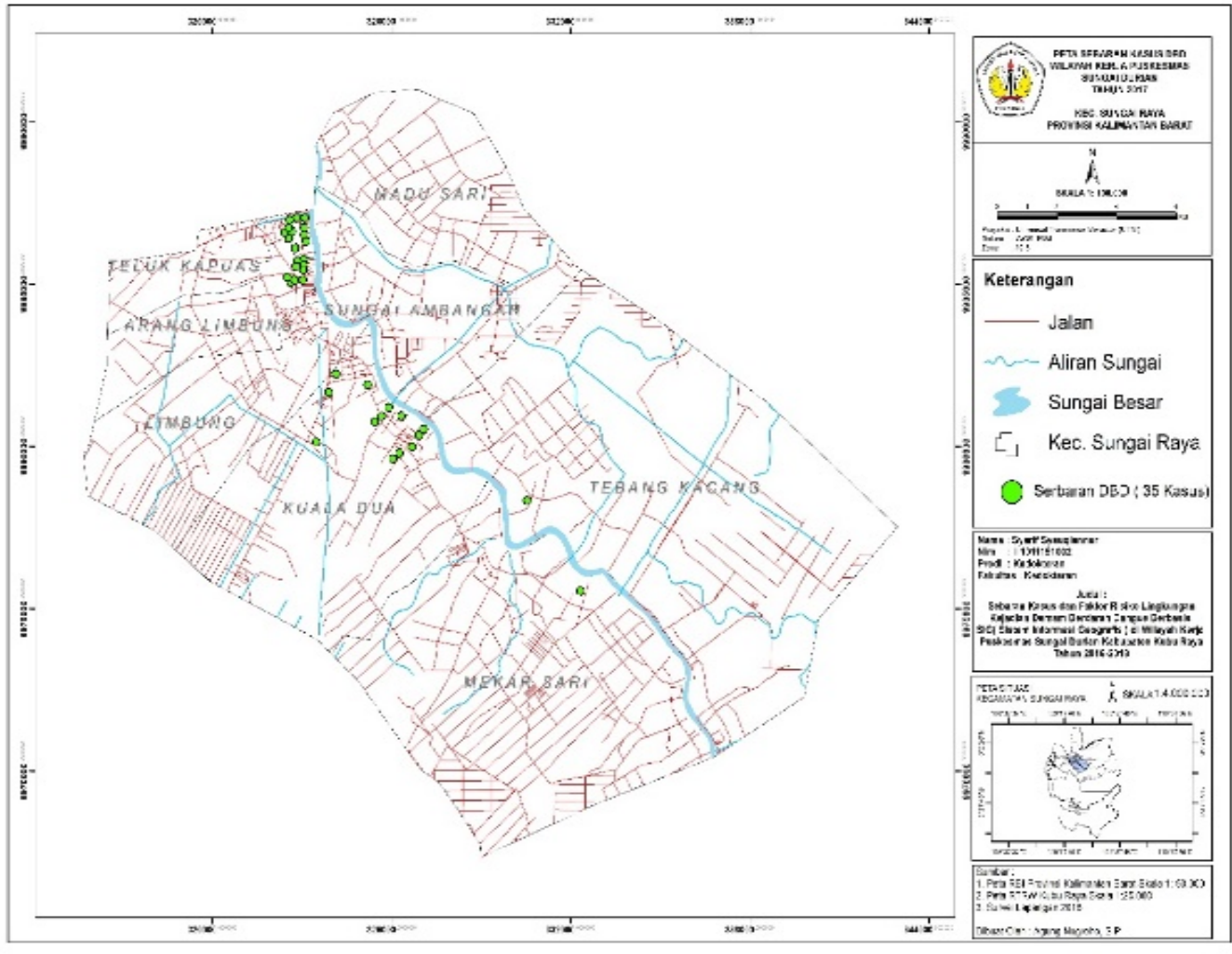

(b) 


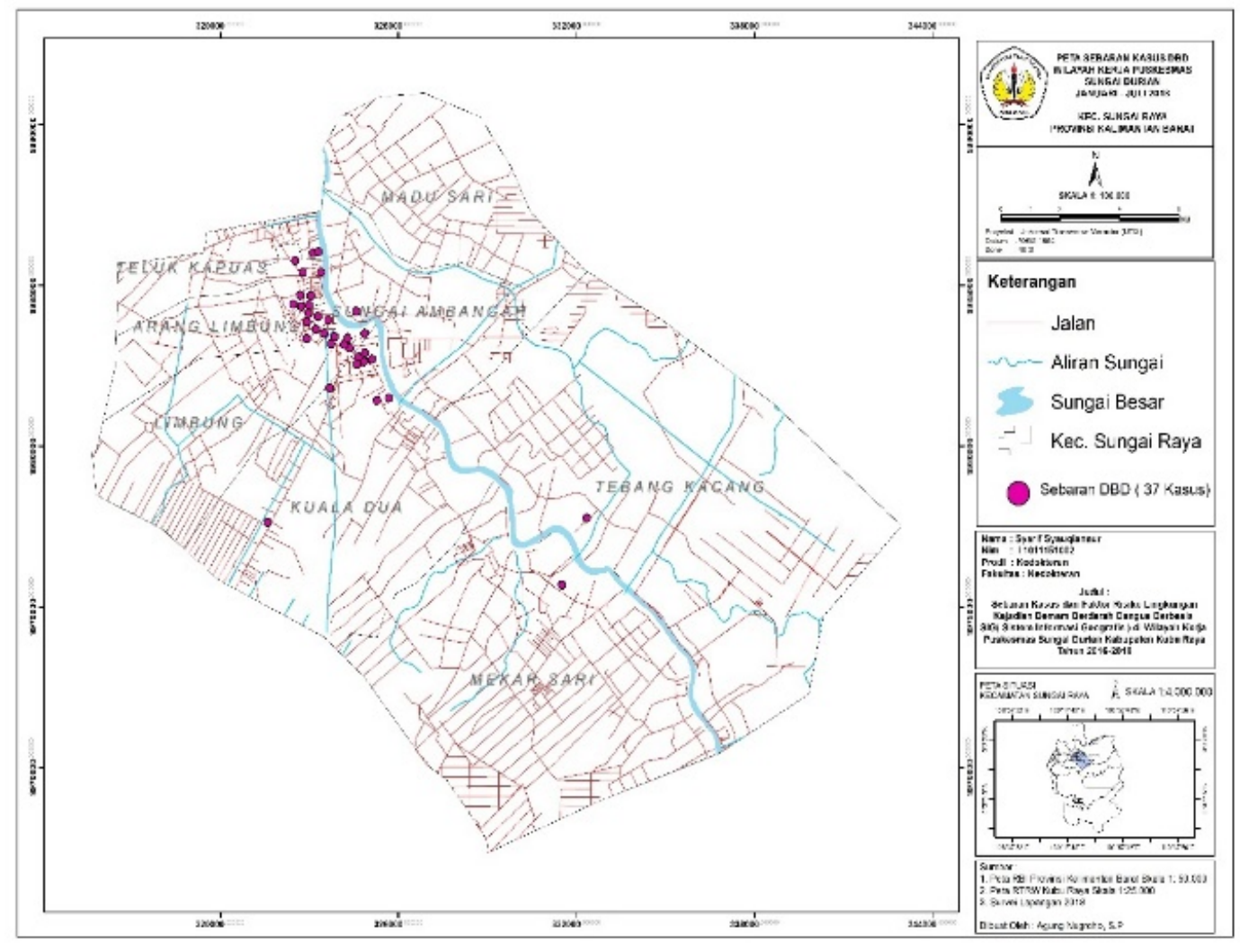

Gambar 4. Peta Distribusi Jumlah Pasien DBD tahun 2016 (a), 2017 (b), Jan-Jul 2018 (c)

Total Kejadian DBD di wilayah kerja Puskesmas Sungai Durian dari tahun 2016 Juli 2018 di dapatkan urutan daerah atau desa dengan angka kejadian kasus DBD dari yang terbanyak hingga yang terendah yaitu desa Kuala Dua (28 kasus), desa Arang Limbung (21 kasus), desa Limbung (17 kasus), desa Teluk Kapuas (14 kasus), desa Mekar Sari dan Tebang Kacang yang memperoleh jumlah kasus sama yaitu 2 kasus, desa Sungai Ambangah (1 kasus), dan desa Madu Sari (0 kasus).

\section{SIMPULAN}

Gambaran spasial dan sebaran kasus Demam Berdarah Dengue (DBD) di wilayah kerja Puskesmas Sungai Durian Kecamatan Sungai Raya yang cenderung meningkat dari tahun 2016 - Juli 2018, yaitu 13 kasus,
35 kasus dan 37 kasus. Dengan sebaran kasus yang tertinggi sampai terendah angka kejadian DBD nya adalah desa Kuala Dua (28 kasus), desa Arang Limbung (21 kasus), desa Limbung (17 kasus), desa Teluk Kapuas (14 kasus), desa Mekar Sari dan Tebang Kacang yang memperoleh kasus sama yaitu 2 kasus, desa Sungai Ambangah (1 kasus), dan desa Madu Sari (0 kasus).

Faktor risiko lingkungan terhadap penyebaran Demam Berdarah Dengue di wilayah kerja Puskesmas Sungai Durian Kabupaten Kubu Raya tahun 2016 -Juli 2018 yaitu untuk variabel suhu udara, mengalami penurunan yaitu dari $27,2^{\circ} \mathrm{C}$ ke $27,0^{\circ} \mathrm{C}$ dengan penambahan kasus DBD yaitu dari 13 orang menjadi 35 orang. Kemudian variabel curah hujan, mengalami penurunan yaitu dari 409,0 
$\mathrm{mm} /$ hari ke 275,9 $\mathrm{mm} /$ hari dengan penambahan kasus DBD yaitu dari 13 orang menjadi 35 orang. Kemudian Kepadatan penduduk yang paling tinggi terletak di desa Limbung yaitu 116,7/km2 dengan kejadian DBD sebanyak 17 kasus, dan terakhir yaitu variabel penggunaan kawat kasa pada ventilasi rumah masih sangat kecil hanya 19 rumah (22,4\%) dari total 85 rumah pasien kasus DBD.

\section{DAFTAR PUSTAKA}

1. Kementerian Kesehatan RI. Kebijaksanaan program P2-DBD dan situasi terkini DBD Indonesia. Jakarta: Kementerian Kesehatan RI; 2016. Diunduh dari: [Link].

2. Centers for Disease Control and Prevention. Epidemiology Dengue [website]. Diakses dari: [Link].

3. World Health Organization. Dengue and Severe Dengue. Geneva: World Health Organization; 2014. [Link].

4. Dinas Kesehatan Provinsi Kalimantan Barat. Profil Kesehatan Provinsi Kalimantan Barat Tahun 2015. Pontianak: Dinas Kesehatan Provinsi Kalimantan Barat; 2016.

5. Dinas Kesehatan Kabupaten Kubu Raya. Data Penderita Demam Berdarah Dengue Kab/Kota, Kecamatan, dan per Wilayah Puskesmas. Kubu Raya: Dinas Kesehatan Kabupaten Kubu Raya; 2017.

6. Puskesmas Sungai Durian. Data Penderita DBD Wilayah Kerja Puskesmas Sungai Durian 20162018. Kubu Raya: Puskesmas Sungai Durian; 2018.

7. Achmadi UF. Manajemen Demam Berdarah Berbasis Wilayah. Buletin Jendela Epidemiologi. 2010; 2:15-20. Diunduh dari: [Link].

8. Indriasih E. Sistem informasi geografis (SIG) dalam bidang kesehatan masyarakat. Buletin Penelitian Sistem Kesehatan. 2008; 11(1):99-104. [Link].

9. World Health Organization, Regional Office for South-East Asia. Comprehensive guideline for prevention and control of dengue and dengue haemorrhagic fever. New Delhi: World Health Organization, Regional Office for South-East Asia; 2011. [Link]

10. Abdullah AZ, Nawi R, Sibe A. Faktor Risiko Kejadian Demam Berdarah Dengue di Kecamatan Tempe Kabupaten Wajo 2009. Media Kesehatan Masyarakat Indonesia. 2010; 6(4):198-203. [Link]

11. Puskesmas Sungai Durian. Laporan Profil Kesehatan tahun 2016. Kubu Raya: Puskesmas Sungai Durian; 2016.

12. Kantor Kecamatan Sungai Raya. Profil Kecamatan Tahun 2016. Kubu Raya: Kantor Kecamatan Sungai Raya; 2017.

13. Nisaa A, Hartono H, Sugiharto E. Analisis Spasial Dinamika Lingkungan Terkait Kejadian Demam Berdarah Dengue Berbasis Sistem Informasi Geografis Di Kecamatan Colomadu, Kabupaten Karanganyar. Journal of Information Systems for Public Health. 2016; 1(2):23-8. [Link]

14. Direktorat Pengendalian Penyakit dan Penyehatan Lingkungan. Penemuan dan Tatalaksana Penderita Demam Berdarah Dengue. Jakarta: Kementerian Kesehatan RI; 2010.

15. Yasin M. Hubungan variabilitas iklim (suhu, curah hujan, hari hujan dan kecepatan angin) dengan insiden Demam Berdarah Dengue di Kota Bogor 2004-2011. [Skripsi]. Depok: Fakultas Kesehatan Masyarakat Universitas Indonesia; 2012. 
16. Kurniawati R. Analisis Spasial Sebaran Kasus Demam Berdarah Dengue di kabupaten Jember tahun 2014. [Skripsi]. Universitas Jember; 2015. Diunduh dari: [Link].

17. Peraturan Menteri Kesehatan Indonesia Nomor 1077/MENKES/PER/V/2011. Pedoman Penyehatan Udara Dalam Ruang Rumah. Jakarta: Kementerian Kesehatan RI; 2011.

18. Yatim F. Karakteristik Lingkungan Fisik, Biologi dan Sosial Penyakit Akibat Nyamuk. Jurnal Litbang Depkes RI. 2007.

19. Maria I, Ishak H, Selomo M. Faktor Risiko Kejadian Demam Berdarah Dengue (DBD) di Kota Makassar Tahun 2013. Penelitian tidak terpublikasi. Makassar: Universitas Hasanuddin; 2013. [Link]

20. Yusnia S. Analisis Spasiotemporal Kasus DBD Di Kecamatan Tembalang Bulan Januari-Juni 2009. [Skripsi]. Semarang: Universitas Diponegoro; 2010.

21. Umaya R, Faisya AF, Sunarsih E. Hubungan Karakteristik Pejamu, Lingkungan Fisik Dan Pelayanan Kesehatan Dengan Kejadian Demam Berdarah Dengue (DBD) Di Wilayah Kerja Puskesmas Talang Ubi Pendopo Tahun 2012. Jurnal Ilmu Kesehatan Masyarakat. 2013; 4(3):262-9. [Link] 